\title{
Bráð kransæðaheilkenni á Landspítala á árunum 2003-2012
}

\author{
Gestur Porgeirsson ${ }^{1,2}$ læknir \\ Birna Björg Másdóttir ${ }^{3}$ læknir \\ Pórarinn Guð̃nason ${ }^{1,2}$ læknir \\ María Heimisdóttir ${ }^{2,3}$ læknir
}

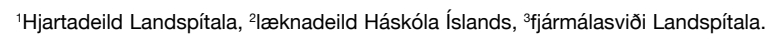

Fyrirspurnum svarar Gestur Porgeirsson, gesturth@landspitali.is

\section{Inngangur}

Á síðustu áratugum hefur tilfellum bráðra kransæðaheilkenna (acute coronary syndromes) á Vesturlöndum farið fækkandi eftir að hafa náð hámarki á 8. og 9. áratug síðustu aldar. ${ }^{1}$ Svipuð próun hefur orðið hér á landi og voru ný tilfelli vegna kransæðastíflu og dauðsföll af hennar völdum flest í kringum $1980 .^{2}$ Enda pótt peim hafi síðan farið fækkandi hafa komið fram vísbendingar í erlendum rannsóknum um að NSTEMI-tilfellum hafi farið fjölgandi á sama tíma og STEMI-tilfellum hafi fækkað umtalsvert. Í stórri rannsókn frá Bandaríkjunum kom fram að aldursstaðlað nýgengi STEMI lækkaði um 62\% á árunum 1999 til 2008. ${ }^{3}$

Í rannsókn sem tók til um tveggja milljóna sjúklinga með STEMI og NSTEMI á rúmlega 2000 spítölum í Bandaríkjunum á árunum 1990-2006 kom fram að samtímis mikilli fækkun á STEMI varð jafnframt hlutfallsleg aukning á NSTEMI. pegar mælingar á trópóníni (TnT) hófust varð greinileg fjölgun á NSTEMI-tilfellum, sem hafði pó farið fjölgandi áður en sú næma greiningaraðferð var tekin upp. ${ }^{4}$ Kenningar eru um að sjúklingar sem áður greindust með hvikula hjartaöng falli nú fleiri í NSTEMI-hópinn en áður með tilkomu TnT-mælinga. Pá hefur verið sýnt fram á að greiningar á hjartadrepi hefðu orðið um $20 \%$ færri ef eingöngu hefði verið stuðst við CKMB-mælingar. ${ }^{5}$

Pessar breytingar í faraldsfræði kransæðasjúkdómsins voru ekki fyrirsjáanlegar, en næmari greiningaraðferðir, breytt samsetning áhættupátta, eldri sjúklingar og meðferð með ýmsum hjartalyfjum hafa haft áhrif á pessa próun. ${ }^{6,7}$

Samkvæmt uppgjöri, sem byggðist á niðurstöðum frá 30 Evrópulöndum, var nýgengi bráðs hjartadreps á bilinu 90-312 tilfelli/100.000 íbúa á ári. Nýgengi innlagna á sjúkrahús vegna STEMI var í pessum löndum 44-142 tilfelli/100.000 á ári. Fyrir heila pjóð er skráningin í sænska gagnagrunninn (RIKS-HIA) talin mjög áreiðanleg, en par var á árinu 2007 nýgengi STEMI 66 tilfelli/100.000 á ári. $^{8}$

\begin{abstract}
Á G R I P
Inngangur

Á síðustu áratugum hafa orðið miklar breytingar á faraldsfræði kransæðasjúkdóms á Vesturlöndum. Með pessari rannsókn er kannað nýgengi bráđra kransæðaheilkenna á Landspítala árin 2003-2012.

\section{Efniviður og aðferð̌ir}

Allir sjúklingar með bráð kransæðaheilkenni innlagðir á Landspítala voru rannsakaðir á tímabilinu. Bráð kransæđaheilkenni eru hvikul hjartaöng, brátt hjartadrep án ST-hækkana (NSTEMI) og brátt hjartadrep með ST-hækkun (STEMI). Upplýsinga var aflað úr sjúkraskrám og gagnagrunnum Landspítala og breytingar á tímabilinu skoðaðar.

Niðurstöður

Sjúklingar með bráđ kransæðaheilkenni voru 7502. STEMI-tilfelli voru 98/100.000 íbúa árið 2003 en 63 árið 2012 sem er fækkun um tæp $36 \%$. Leiðrétt fyrir aldri kom fram marktæk árleg lækkun $(p<0,05)$ á nýgengi STEMI hjá körlum um 5,5\% og konum 5,3\%. Nýgengi NSTEMI var 54/100.000 íbúa árið 2003 en 93 árið 2012. Sjúklingar með hvikula hjartaöng voru 56/100.000 íbúa árið 2003, 115 árið 2008 og 50 árið 2012. Breytingar á tíðnitölum fyrir NSTEMI og hvikula hjartaöng voru ekki tölfræðilega marktækar. Konur voru um 35\% sjúklinga með NSTEMI en um $30 \%$ sjúklinga með STEMI og hvikula hjartaöng. Meðalaldur NSTEMI-sjúklinga var 72 ár, um 5 árum hærri en sjúklinga með STEMI og hvikula hjartaöng. Um 30\% bráðra kransæðatilfella komu af landsbyggðinni.
\end{abstract}

\section{Ályktun}

Á árunum 2003-2012 varð 5\% árleg tölfræðilega marktæk lækkun í nýgengi STEMI en á sama tíma var tilhneiging til aukningar á nýgengi NSTEMI, sem í lok tímabilsins var orðið algengasta heilkennið. Nýgengi hvikullar hjartaangar próaðist með óvenjulegum hætti og er umhugsunarefni hvort andlegt álag í pjóđfélaginu á rannsóknartímabilinu hafi haft par áhrif.

https://doi.org/10.17992//bl.2019.02.217

Á Íslandi lækkaði nýgengi kransæðastíflu (samheiti yfir hjartadrep með ST- hækkun og hjartadrep án ST-hækkunar) um 66\% frá 1981 til 2006 og er pað meginástæða pess að dauðsföllum vegna sjúkdómsins fækkaði um $80 \%$ á pví tímabili. Hagstæðar breytingar í helstu áhættupáttum kransæðasjúkdómsins eru taldar skýra 73\% af fækkun dauðsfalla vegna kransæðastíflu á Íslandi. Einkum er um að ræða lækkun í heildarkólesteróli, fækkun peirra sem reykja og lækkun blóðprýstings meðal pjóðarinnar. Að öðru leyti er lækkun dánartíðni talin tengjast bættri meðferð. ${ }^{9}$ Hjartasjúkdómar hafa um langt árabil verið algengasta dánarorsök á Íslandi en eru nú í öðru sæti á eftir krabbameinum. ${ }^{10}$ 


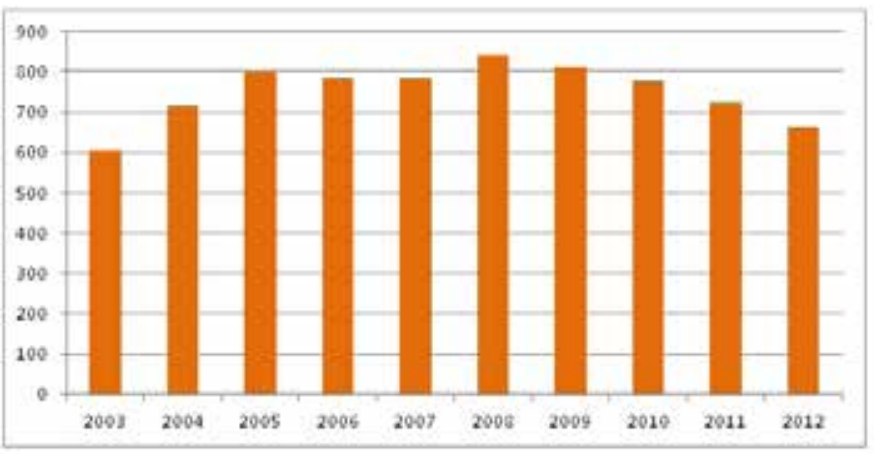

Mynd 1. Heildarfjöldi brádra kransæðatilfella á Landspítala 2003-2012.

Í pessari rannsókn er kannað nýgengi bráðra kransæðaheilkenna á Landspítala árin 2003-2012. Nýgengi var jafnframt skoðað eftir búsetu sjúklinga (eftir póstnúmerum) en áhugavert pótti að kanna hve hátt hlutfall sjúklinga með bráð kransæðaheilkenni á Landspítala kemur af landsbyggðinni.

\section{Efniviður og aðferðir}

Inn í rannsóknina voru teknir allir sjúklingar, yngri sem eldri, sem uppfylltu skilmerki bráðra kransæðaheilkenna og voru lagðir inn á Landspítala árin 2003-2012. Til bráðra kransæðaheilkenna teljast hvikul hjartaöng (unstable angina pectoris I20.0, I20.1), brátt hjartadrep án ST-hækkana á hjartariti, NSTEMI (Non-ST Elevation Myocardial Infarction I21.4) og brátt hjartadrep með ST- hækkun á hjartariti, STEMI (ST Elevation Myocardial Infarction I21.0, I21.1, I21.2, I21.3, I21.9). Notaðar voru útskriftargreiningar í sjúkraskrám.

Sjúklingar með bráð kransæðaheilkenni hafa að jafnaði, en ekki alltaf, hin dæmigerðu einkenni kransæðasjúkdóms, hjartaverk hjartaöng. STEMI-sjúklingar eru að jafnaði með fleygdrep í gegnum hjartavöðvann, hafa ST-hækkun á hjartariti og hækkun á TnT. Dæmigert er að NSTEMI-sjúklingar hafi drep undir hjartapeli, hækkun á TnT og oft ST-lækkanir á hjartariti. Í hvikulli hjartaöng er ekki hækkun á TnT en vægar hjartalínuritsbreytingar geta verið til staðar. Sjúklingar með fyrri sögu um hjartadrep voru ekki útilokaðir. Sjúklingar sem voru lagðir inn eftir hjartastopp utan spítala sem rakið var til bráðs kransæðasjúkdóms voru teknir með í pessari rannsókn. Langflestir sjúklinganna voru greindir og meðhöndlaðir á hjartadeild eða gjörgæsludeildum Landspítala.

Stuðst var við gögn úr klínískum gagnagrunnum spítalans, einkum vöruhúsi gagna.

Kannaður var fjöldi tilfella bráðra kransæðaheilkenna og skiptingin á milli STEMI og NSTEMI. Skipting eftir aldri og kyni var skoðuð. Könnuð var sjúkrahúsdánartíðni innan 30 daga frá innlögn, heildardánartíðni innan 30 daga frá innlögn svo og dánartíðni að einu ári liðnu. Hin næma TnT-rannsókn var tekin upp á fyrri hluta rannsóknartímabilsins og var fjöldi peirra mælinga skráđur fyrir hvert ár.

Til höfuðborgarsvæðis teljast Reykjavíkurnúmerin 101-116, Seltjarnarnes 170, Kópavogur 200-203, Mosfellsbær 270-271, Garðabær 210, Hafnarfjörður 220-221 og Álftanes 225. Önnur póstnúmer eru af landsbyggðinni.
Einu hjartapræðingastofur landsins eru á Landspítala og hefur sólarhringsvakt fyrir kransæðapræðingar verið par frá árinu 2003.

Tölfræðileg úrvinnsla: Nýgengi fékkst með pví að deila heildaríbúafjölda í hverjum aldurshópi upp í fjölda tilfella í peim hópi (í heild, konur, karlar). Heildarfjöldi Íslendinga árið 2012 var notaður sem viðmið til að reikna aldursstaðlað nýgengi (Age standardized incidence rates, ASR). Poisson-aðhvarfsgreining var notuð til að meta aldursstaðlað nýgengi á tímabilinu. Pegar við átti var notuð neikvæð tvíliða aðhvarfsgreining (negative binomial regression).

Leyfi fyrir pessari rannsókn var fengið hjá framkvæmdastjóra lækninga á Landspítala og sampykki hjá Persónuvernd og siðanefnd spítalans.

\section{Niðurstöður}

Bráð kransæðatilfelli á Landspítala á árunum 2003-2012 voru samtals 7502 (mynd 1). Flest voru tilfellin á árinu 2008, eða 840. Við lok tímabilsins var heildarfjöldi bráðra kransæðaheilkenna um $10 \%$ hærri en við upphaf pess. Pegar tekið var tillit til fólksfjölgunar var heildarfjöldi fyrir hverja 100.000 íbúa á ári pó nánast sá sami, pað er 208 árið 2003 og 206 árið 2012. Árið 2008 greindust flest tilfelli með hvikula hjartaöng, eða 367, sem eru rúmlega tvöfalt fleiri tilfelli en við upphaf og lok tímabilsins. NSTEMI-tilfellin voru flest kransæðaheilkenna, eða samtals 2590. Flest voru NSTEMI-tilfellin árið 2005, eða 305. Eftir pað var fjöldi NSTEMI- tilfella svipaður með ákveðnum frávikum. STEMI-tilfellin voru fæst á tímabilinu, eða 2333, flest 293 árið 2004 og fæst árið 2012, eða 202.

Á mynd 2 er sýndur fjöldi kransæðaheilkenna á hverja 100.000 íbúa á ári, en íbúum hafði fjölgað úr 290.490 árið 2003 í 321.585 árið 2012. Pannig voru STEMI-tilfelli 98/100.000 íbúa árið 2003 og 63/100.000 árið 2012, eða 35,7\% færri. NSTEMI-tilfellin voru 54/100.000 íbúa árið 2003 og 93/100.000 árið 2012, eða 72,2\% fleiri. Flest voru NSTEMI-tilfellin pó árið 2005, eða 102 á 100.000 íbúa.

TnT-mælingar jukust hratt snemma á tímabilinu. Pannig voru fjórfalt fleiri slíkar mælingar gerðar á Landspítala árið 2005 en árið 2004, eða 15.485, á móti 3886. Peim fjölgaði svo enn frekar og voru að jafnaði um 20.000 mælingar á ári eftir pað.

Meðalaldur sjúklinga með NSTEMI var 72,2 ár, hjartaöng 66,7 ár og STEMI 66,2 ár (mynd 3). Konur voru hlutfallslega flestar með NSTEMI, eða $34,5 \%$, með hjartaöng voru $28,5 \%$ og með STEMI

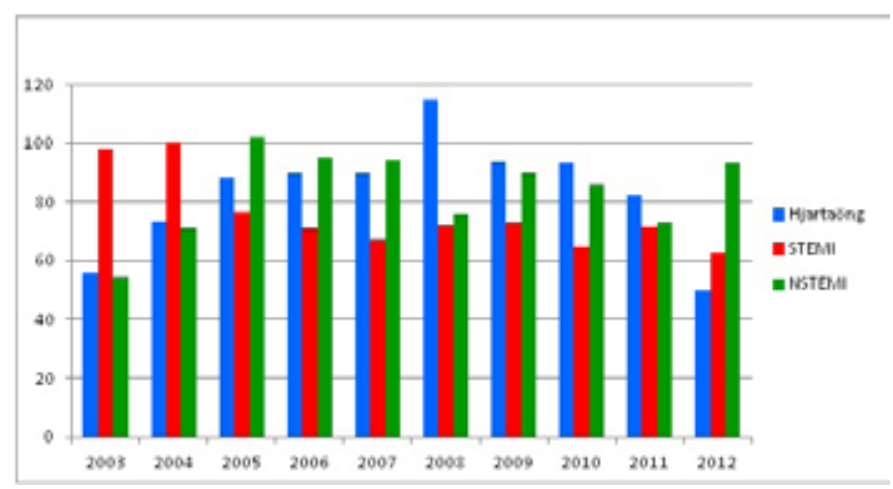

Mynd 2. Bráð kransæðaheilkenni á hverja 100.000 íbúa. 


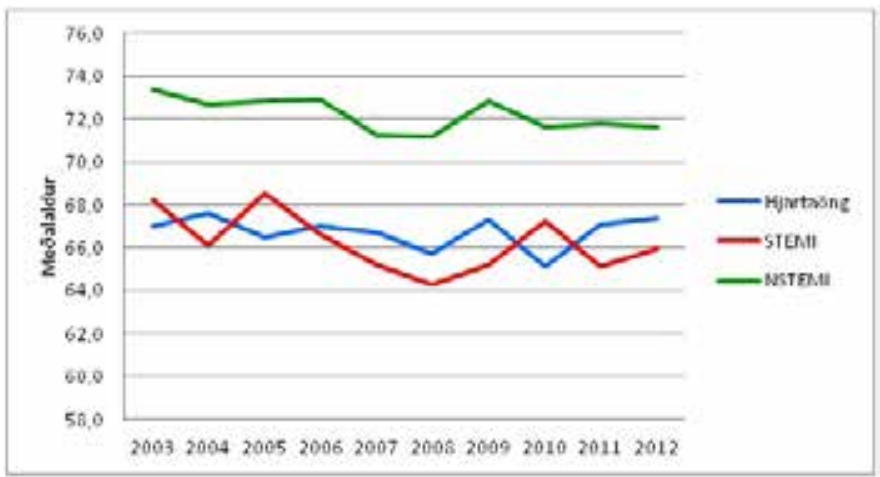

Mynd 3. Meðalaldur sjúklinga með bráð kransæðaheilkenni (STEMI, NSTEMI og hvikula hjartaöng).

28,9\%. Sjúkrahúsdánartíðni STEMI-sjúklinga innan 30 daga frá innlögn var að meðaltali 10,3\%. Nokkur munur var á dánartíðni milli ára, hæst 15\% árið 2003, 13,4\% árið 2012 og 13,1\% árið 2005, en á pessum árum voru hlutfallslega flestir sjúklingar með greininguna hjartastopp. Flest hin árin var sjúkrahúsdánartíðnin um 8\%. Sjúkrahúsdánartíðni NSTEMI-sjúklinga innan 30 daga frá innlögn var að meðaltali 6,3\% en nokkuð mismunandi eftir árum, eða frá rúmlega 2\% árið 2012 og upp í rúmlega 9\% árið 2006.

Á árunum 2008-2012 var skráning á heimilisfangi/póstnúmeri ítarleg svo ekki vantaði upplýsingar um heimilisfang sjúklinga með STEMI nema í 34 tilvikum (4-11 á ári). Á pessum 5 árum komu 723 með STEMI af höfuðborgarsvæðinu, eða að meðaltali 71/ 100.000 íbúa á ári, og af landsbyggðinni 341 STEMI, eða 58/100.000 á ári. Árið 2012 voru STEMI sjúklingar af landsbyggðinni aðeins 2/100.000 færri en STEMI af höfuðborgarsvæðinu en mestur munur var árið 2009, eða 22/100.000 færri af landsbyggðinni. Аð meðaltali voru 13/100.000 færri sjúklingar á ári með STEMI af landsbyggð en frá höfuðborgarsvæðinu pessi 5 ár. Með NSTEMI voru að meðaltali 91/100.000 á ári af höfuðborgarsvæðinu og 66 af landsbyggðinni. Með hvikula hjartaöng voru að meðaltali 95/100.000 á ári af Reykjavíkursvæðinu og 70/100.000 á ári af landsbyggðinni. Munurinn eftir búsetu var um 25 sjúklingar/100.000 á ári að meðaltali, bæði fyrir NSTEMI og hvikula hjartaöng og meiri breytileiki milli ára en hjá STEMI-sjúklingunum.

Tafla I sýnir breytingar í aldursstöðluðu nýgengi bráðra kransæðaheilkenna meðal karla og kvenna á árunum 2003-2012 samkvæmt Poisson-aðhvarfsgreiningu. Pegar við átti var notuð neikvæð tvíliða aðhvarfsgreining. Rúmlega 5\% fækkun STEMItilfella á ári varð hjá bæði körlum og konum $(\mathrm{p}<0,05)$. Ekki voru marktækar breytingar hvað petta varðar hjá sjúklingum með NSTEMI og hvikula hjartaöng. Vegna pess hve fáir sjúklingar undir 30 ára aldri voru með STEMI, voru peir ekki teknir með í pessari úrvinnslu. Aldurssértækt nýgengi (age-specific incidence) var kannað hjá mismunandi aldurshópum sjúklinga með STEMI. Рað er tilhneiging til fækkunar á STEMI í flestum aldurshópum, en marktæk breyting um slíkt er pó fyrst og fremst hjá elstu aldurshópunum, konum 90-99 ára og körlum 70-79 ára og 90-99 ára. Fyrstu prjú ár rannsóknarinnar koma 168 karlar í hópnum 7079 ára með STEMI en síðustu prjú ár hennar eru peir aðeins 78 talsins. Fækkun í pessum aldurshópi síðustu prjú ár tímabilsins
Tafla I. Breytingar á aldursstöðluðu nýgengi STEMI, NSTEMI og hvikullar hjartaangar (UA) meðal karla og kvenna 2003-2012.

\begin{tabular}{|c|c|c|c|c|c|}
\hline \multicolumn{6}{|c|}{ Karlar } \\
\hline & $\begin{array}{l}\text { Ný } \\
\text { tilfelli } \\
n\end{array}$ & $\begin{array}{l}\text { Ný- } \\
\text { gengi- } \\
\text { hlutfall }\end{array}$ & $\mathrm{P}$ & $\begin{array}{c}\text { Árleg } \\
\text { hlutfalls- } \\
\text { breyting }\end{array}$ & $\begin{array}{c}\text { Árleg } \\
\text { prósentubreyting } \\
\text { (95\% öryggisbil) }\end{array}$ \\
\hline STEMI & 1661 & 0,94 & * & $-0,055$ & $-5,55(-3,6$ to $-7,45)$ \\
\hline NSTEMI & 1700 & 1,00 & & 0,004 & $0,42(-3,34$ to 4,41$)$ \\
\hline UA & 1845 & 0,99 & & $-0,004$ & $-0,439(-5,81$ to 5,2$)$ \\
\hline \multicolumn{6}{|l|}{${ }^{*} \mathrm{P}<0,05$} \\
\hline \multicolumn{6}{|c|}{ Women } \\
\hline & $\begin{array}{l}\text { Ný } \\
\text { tilfelli } \\
n\end{array}$ & $\begin{array}{l}\text { Ný- } \\
\text { gengi- } \\
\text { hlutfall }\end{array}$ & $\mathrm{P}$ & $\begin{array}{c}\text { Árleg } \\
\text { hlutfalls- } \\
\text { breyting }\end{array}$ & $\begin{array}{c}\text { Árleg } \\
\text { prósentubreyting } \\
\text { (95\% öryggisbil) }\end{array}$ \\
\hline STEMI & 672 & 0,94 & * & $-0,053$ & $-5,34(-8,30$ to $-2,27)$ \\
\hline NSTEMI & 890 & ,00 & & 0,006 & $0,67(-3,07$ to 4,57$)$ \\
\hline UA & 734 & 0,98 & & $-0,010$ & $-1,07(-6,31$ to 4,45$)$ \\
\hline
\end{tabular}

${ }^{*} \mathrm{P}<0,05$

vegur hvað pyngst í pví að meðalaldur STEMI-sjúklinga fer ekki hækkandi á tímabilinu.

\section{Umræða}

Fækkun STEMI en aukning á NSTEMI

Meginniðurstaða pessarar rannsóknar er sú að á árunum 20032012 fækkaði alvarlegustu tilfellum kransæðastíflu, STEMI-tilfellum, um tæp 36\%. Leiðrétt fyrir aldri var um marktæka árlega fækkun STEMI að ræða hjá báðum kynjum, um 5\% (p<0,05) eins og sést í töflu I. Marktæk fækkun tilfella var aðallega hjá eldri aldurshópunum pótt tilhneigingar gætti einnig hjá peim yngri. NSTEMI-tilfellum fjölgaði um rúm $72 \%$ á tímabilinu og við lok pess var NSTEMI orðið algengasta kransæðaheilkennið. Pannig var hjartadrep með ST-hækkun, STEMI, algengara en hjartadrep án ST-hækkana, NSTEMI, í upphafi tímabilsins, en petta hafði snúist við í lok pess. Fjölgun NSTEMI var pó ekki tölfræðilega marktæk.

Á pví 10 ára tímabili sem rannsóknin tekur til verða pannig mjög athyglisverðar breytingar á nýgengi hinna priggja bráðu kransæðaheilkenna. Að teknu tilliti til fólksfjölgunar er tilfellafjöldinn pó nánast óbreyttur við upphaf og enda tímabilsins. Fjöldi sjúklinga með hvikula hjartaöng er hinn sami árið 2003 og 2012 eftir að hafa verið rúmlega tvöfalt meiri um miðbik tímabilsins. Í upphafi tímabils eru NSTEMI-tilfellin 26,1\% af heildarfjölda bráðra kransæðatilfella en við lok pess $45,2 \%$. Á sama tíma voru STEMI-tilfellin $47,1 \%$ af heildarfjöldanum í upphafi tímabils en $30,6 \%$ við lok pess.

Á árinu 2005 fjölgaði TnT mælingum fjórfalt á Landspítala og sama ár fjölgaði NSTEMI-tilfellum um helming en STEMI- tilfellum fækkaði. Líklegt er að einhver hluti sjúklinga sem áður voru greindir með hvikula hjartaöng á grunni eðlilegs CKMB hafi flust í NSTEMI-hópinn með tilkomu TnT-mælinga, en pað hefur verið 
reynslan erlendis ${ }^{4,5}$ Pví hefði mátt búast við færri með hvikula hjartaöng. Hins vegar fjölgaði sjúklingum með hvikula hjartaöng stöðugt til ársins 2008 og voru pá rúmlega tvöfalt fleiri en við lok og upphaf rannsóknar. Til að skýra pá próun parf pví að líta til annarra pátta, meðal annars væri áhugavert að skoða betur hugsanleg áhrif andlegs álags í kjölfar hruns og náttúruhamfara sem urðu á Íslandi á pessu tímabili.

\section{Aldur og kyn}

NSTEMI-sjúklingar voru að meðaltali um 5 árum eldri en sjúklingar með STEMI og hvikula hjartaöng. Pekkt er að eldri sjúklingar eru líklegri en peir yngri til að hafa NSTEMI og hefur pað verið talið stafa meðal annars af pví að sjúkdómurinn er í fleiri kransæðum og dreifðari en hjá peim yngri. Pá eru peir eldri oftar með fyrri sögu um hjartadrep, háprýsting og aukna veggpykkt í vinstri slegli. ${ }^{11}$ Jafnan er rætt um að meðalaldur pjóðarinnar fari hækkandi með hverju ári. Раð er pví athyglisvert að meðalaldur sjúklinganna er ekki hærri við lok tímabils en við upphaf pess. Pegar aldurshópar voru skoðaðir sérstaklega (aldurssértækt nýgengi) var sýnt fram á að fækkun STEMI-tilfella var mest áberandi í eldri aldurshópunum, sem gæti verið hluti skýringarinnar. Svipaðar niðurstöður hafa verið birtar í Ástralíu, en par kom jafnframt fram óvænt aukning í tíðni hjartadreps hjá ungum konum. ${ }^{12}$

Bráð kransæðaheilkenni eru mun algengari hjá körlum en konum. Karlar eru rúmlega 70\% af sjúklingum með STEMI og hvikula hjartaöng en rúmlega 65\% sjúklinga með NSTEMI. Af kransæðaheilkennum voru konur pví hlutfallslega flestar meðal NSTEMIsjúklinga. Í Grace-rannsókninni voru svipaðar niðurstöður hvað petta varðar. ${ }^{11}$ Horfur STEMI-sjúklinga fara versnandi með hækkandi aldri og gildir pað um bæði kyn, eins og sýnt var fram á í víðtækri rannsókn frá Evrópu. Horfur kvenna hafa einnig verið taldar lakari en karla, en að miklu leyti skýrist sá munur af ólíkum grunnpáttum og færri kransæðavíkkunum hjá konum. Pegar leiðrétt hefur verið fyrir pessum páttum kemur ekki fram munur á dánartíðni karla og kvenna. ${ }^{13}$ Pekkt er að kransæðasjúkdómurinn hefur nokkuð ólíka birtingarmynd hjá konum og hefur pað að hluta til verið skýrt með verndandi áhrifum östrogens gagnvart kölkun í æðakerfinu. ${ }^{14}$ Aðrir hafa bent á að östrogen virðist minnka bólgu í kalkskellum á innra borði kransæða, sem eykur stöðugleika peirra. ${ }^{15}$

\section{Áhrif lyfja á sjúkdómsferilinn}

Rannsóknir benda til pess að hafi sjúklingur sem er lagður inn með brátt kransæðaheilkenni verið á lyfjum sem innihalda acetylsalicylsýru, beta-blokka, ACE-hemla og statínlyf, eitt eða fleiri, séu marktækt minni líkur á að um STEMI sé að ræða en ef sjúklingur hefur ekki verið á neinum slíkum lyfjum fyrir. Pessi hjartalyf virðast pví hafa mildandi áhrif á sjúkdómsferil hjá sjúklingum með bráð kransæðaheilkenni. ${ }^{16,17}$

Pví væri áhugavert að kanna hvort vísbendingar séu um að breytingar á notkun pessara lyfjaflokka á rannsóknartímabilinu gætu skýrt eitthvað af peim breytingum í sjúkdómsmyndinni, sem við segjum frá hér.

\section{Hjartapræðing - kransæðavíkkun}

Enda pótt bráð hjartapræðing með víkkun hafi verið gerð af og til, einkum að deginum, sem fyrsta meðferð við STEMI, hófst eiginleg sólarhringshjartapræðingarvakt á Landspítala ekki fyrr en í desember 2003. Eftir að sú vakt komst á hefur langstærsti hluti sjúklinga með STEMI, hvar sem peir hafa verið staddir á landinu, verið fluttir með hraði á Landspítala, sem er eina stofnunin sem framkvæmir hjartapræðingar og kransæðaaðgerðir á landinu. Pegar petta er skoðað nánar á Landspítala eru heldur færri STEMIsjúklingar af landsbyggðinni en af höfuðborgarsvæðinu sem nemur um 13 sjúklingum/100.000 á ári að jafnaði. STEMI-sjúklingar utan af landi höfðu í mörgum tilvikum fengið segaleysandi meðferð vegna langs flutningstíma og var pá reynt að præða pá innan 24 klukkustunda. ${ }^{18}$ Stór hluti peirrra sem hafa NSTEMI og hvikula hjartaöng hafa að jafnaði einnig verið sendir á Landspítala til pess að undirgangast hjartapræðingu og frekari meðferð. Í peim tilvikum var yfirleitt ekki pörf á bráðri præðingu en sú aðgerð gjarnan gerð innan eins til tveggja sólarhringa. ${ }^{19}$

Pannig virðist mega álykta að langflestir sjúklingar á landinu með bráð kransæðaheilkenni, einkum pó STEMI, sem ekki hafa leitt til skyndidauða á vettvangi séu lagðir inn á Landspítala til meðferðar og rannsókna. Meginástæða pess er væntanlega sú að rétt pykir að vera nærri hjartapræðingarstofu meðan ástand er jafn óstöðugt og búast má við pegar um brátt kransæðaheilkenni er að ræða. Sá munur sem er pó til staðar á fjölda sjúklinga á Landspítala með bráð kransæðaheilkenni af höfuðborgarsvæðinu annars vegar og af landsbyggðinni hins vegar getur skýrst af ýmsum ástæðum. Beint liggur við að nefna landfræðilegar og veðurfarslegar ástæður. Sjúklingur getur verið fjarri heilbrigðispjónustu pannig að ekki er tiltæk bráðapjónusta við til dæmis losti eða hjarta- og öndunarstöðvun. Í vissum tilvikum kann sjúklingur að hafa verið of veikur og hrumur til að flytjast á milli landshluta.

\section{Sjúkrahúsdánartíðni}

Sjúkrahúsdánartíðni STEMI-sjúklinga innan 30 daga frá innlögn var að meðaltali 10,3\%, pað er 8,9\% hjá körlum og 13,8\% hjá konum. Töluverður breytileiki er í dánartíðni milli ára. Í samanburði við erlendar rannsóknir er vert að hafa í huga að í mörgum peirra eru hjartastopp og sjúklingar í losti oft ekki teknir með eins og hér var gert, auk pess sem upptökusvæði Landspítala er stórt og dreift, sem getur seinkað pví um nokkrar klukkustundir að kransæðavíkkun eða segaleysandi meðferð geti hafist. Pá er dánartíðni að jafnaði lægri í vísindarannsóknum par sem inntökuskilyrði eru takmörkuð samanborið við rannsókn eins og pessa, par sem niðurstöður eru fengnar frá öllum innlögðum sjúklingum óháð aldri og fyrra heilsufari. ${ }^{20}$

\section{Hrun fjármálakerfis, náttúruhamfarir og andleg áföll}

Árið 2008 hefur verið nefnt ár hrunsins á Íslandi. Borið saman við önnur ár á tímabilinu 2003-2012 voru flestir sjúklingar með bráð kransæðaheilkenni lagðir inn á Landspítala árið 2008. Hvort pað er í einhverju samhengi við hamfarir í náttúrunni eða af manna völdum verður ekki afráðið með pessari rannsókn, en pann 29. maí 2008 reið mikill jarðskjálfti yfir Suðurland og ill tíðindi af 
fjármálum voru í fréttum flesta mánuði ársins. Gengi krónunnar féll mikið á vormánuðum 2008 og algert bankahrun varð í október 2008. Á pví 10 ára tímabili sem litið er til í pessari rannsókn voru flestir sjúklingar með brátt kransæðaheilkenni, sérstaklega hvikula hjartaöng, lagðir inn á Landspítala árið 2008. Hvort sú staðreynd tengist fyrrgreindum áföllum verður pó ekki fullyrt út frá niðurstöðum rannsóknarinnar, en margvísleg gögn liggja fyrir um hættu á hjartasjúkdómum í tengslum við jarðskjálfta og andleg áföll. ${ }^{21}$ I íslenskri rannsókn var raunar sýnt fram á að sjúklingum fjölgaði marktækt á Hjartagátt Landspítala í fyrstu vikunni eftir bankahrunið, sérstaklega var marktæk aukning hjá konum sem fengu sjúkdómsgreiningu um súrefnispurrð í hjarta. ${ }^{22}$ Reykingabann á opinberum stöðum var lögleitt á Íslandi árið 2007, en ýmsar rannsóknir hafa sýnt fram á marktæka fækkun kransæðatilfella í kjölfar slíks reykingabanns. ${ }^{23}$ Mögulegt er að svipaðra áhrifa hafi gætt hér á landi og að bannið hafi átt pátt í breytingum á tíðni bráđra kransæðaheilkenna á seinni hluta tímabilsins. Pá urðu tölverðar breytingar á fjölda innflytjenda á tímabilinu, en í peirra hópi geta verið aðrar reykingavenjur og önnur tíðni áhættupátta en hjá innfæddum Íslendingum. Innflytjendum fjölgaði á fyrri hluta tímabilsins en fækkaði aftur eftir efnahagshrunið 2008. Áhrif pessara fólksflutninga gæti verið vert að skoða nánar.

Par sem langflestir sjúklingar með bráð kransæðaheilkenni eru lagðir inn á Landspítala til frekari greiningar og meðferðar er dregin sú ályktun að pær breytingar sem hafa sést í nýgengi peirra sjúklinga gildi með ákveðnum fyrirvörum fyrir landið allt. Sterkust rök fyrir pví eru hjá STEMI-sjúklingum en mestur fyrirvari á pví hjá sjúklingum með hvikula hjartaöng og NSTEMI, enda getur í seinni tilvikunum, sem ekki eru eins bráð, frekar verið ákveðið að flytja sjúkling ekki tafarlaust á Landspítala til præðingar til dæmis vegna hrumleika, veðurfars eða færðar.

\section{Styrkleiki og veikleiki}

Styrkur rannsóknarinnar felst í pví að yfirgnæfandi meirihluti sjúklinga með bráð kransæðaheilkenni á Íslandi er lagður inn á sama spítalann, Landspítala. Vegna pess eru miklar líkur til pess að allir sjúklingarnir hafi fengið sömu eða svipaðar rannsóknir og meðferð og greiningaraðferðir verið samræmdar. Af peirri ástæðu fást mjög áreiðanlegar upplýsingar um bráð kransæðaheilkenni og vísbendingar um faraldsfræði peirra með pjóðinni. Rannsóknin er afturskyggn með hefðbundna veikleika sem pví fylgja. Pá er vert að hafa í huga að á fyrstu árum trópónínmælinga er mögulegt að pess hafi ekki verið gætt eins vel og síðar að margir sjúkdómar, svo sem hjartabilun, takttruflanir, lungnarek og sýkingar af ýmsu tagi, geta framkallað losun trópóníns frá hjartafrumum án pess að óstöðugur kransæðasjúkdómur með súrefnispurrð sé par frumpáttur. Mögulegar ofgreiningar eru pví veikleiki að pessu leyti. Einhver dæmi eru um að sjúklingar með bráð kransæðaheilkenni, einkum NSTEMI og hvikula hjartaöng, séu ekki sendir á Landspítala, oft ekki treyst í flutning vegna hrumleika eða annarra alvarlegra veikinda. Nýgengistölur á Landspítala eru pá lægri sem pví nemur. Í samanburði á nýgengi á höfuðborgarsvæði og landsbyggð voru tölur óstaðlaðar fyrir aldri. Pá telst pað til veikleika að nokkuð er um liðið síðan gögnum var safnað saman í pessa grein.

Höfundar pakka Ubaldo Benitez Hernandez fyrir aðstoð við tölfræðilega úrvinnslu og Elísabetu Lilju Haraldsdóttur fyrir aðstoð við ritun og uppsetningu greinarinnar.

\section{Heimildir}

1. Ruff CT, Braunwald E. The evolving epidemiology of acute coronary syndromes. Nature Rev 2011; 8: 140-7.

2. Sigfússon N, Sigurðsson G, Agnarsson U, Guðmundsdóttir II, Stefánsdóttir I, Sigvaldason H, et al. Breytingar á tíðn kransæðasjúkdóma á Íslandi. Læknablaðið 2001; 87: $889-96$

3. Yeh RW, Sidney S, Chandra M, Sorel M, Selby JV, Go AS. Population trends in the incidence and outcomes of acute myocardial infarction. N Engl J Med 2010; 262: 2155-64

4. Rogers JR, Frederick PD, Stoehr E, Canto JG, Ornato JP, Gibson CM, et al. Trends in presenting characteristics and hospital mortality among patients with ST elevation and non-ST elevation myocardial infarction in the National Registry of myocardial infarction from 1990 to 2006. Am Heart J 2008; 156: 1024-6.

5. Roger VL, Weston SA, Gerber Y, Killian JM, Dunlay SM, Jaffe AS, et al. Trends in incidence, severity, and outcome of hospitalized myocardial infarction. Circulation 2010; 121: 862-9.

6. Arbab-Zadeh A, Nakano M, Virmani R, Fuster V. Acute coronary events. Circulation 2012; 125: 1147-56.

7. Dudas K, Björck L, Jernberg T, Lappas G, Wallentin L Rosengren A, et al. Differences between acute myocardial infarction and UA: a longitudinal cohort study reporting findings from RIKS-HIA. BMJ open 2012; 2: e002155.

8. Widimsky P, Wijns W, Fajadet J, de Belder M, Knot J, Aaberge L et al. Reperfusion therapy for ST elevation acute myocardial infarction in Europe: description of the current situation in 30 countries. Eur Heart J 2010; 21: $942-57$.
9. Aspelund T, Gudnason V, Magnusdottir BT, Andersen K, Sigurdsson G, Thorsson B, et al. Analysing the large decline in coronary heart disease mortality in the Icelandic population aged 25-74 between the years 1981 and 2006 Plos one 2010 Nov 12; 5: e13957.

10. landlaeknir.is/utgefid-efni/skjal/item29545/ Tíu valdar dánarorsakir. 1996-2017.

11. Avezum A, Makdisse M, Spencer F, Gore JM, Fox KA Montalescot Get al. Impact of age on management and outcome of acute coronary syndrome: observations from the Global Registry of Acute Coronary Events (GRACE). Am Heart J 2005; 149: 67-73.

12. Nedkoff LJ, Briffa TG, Preen DB, Sanfilippo FM, Hung J, Ridout SC, et al. Age- and sex specific trends in the incidence of hospitalized acute coronary syndromes in Western Australia. Circ Cardiovasc Qual Outcomes 2011; 4: $557-64$.

13. Rosengren A, Wallentin L, Gitt AK, Behar S, Battler A Hasdai D. Sex, age, and clinical presentation of acute coronary syndromes. Eur Heart J 2004; 25: 663-70.

14. Mendelsohn ME, Karas RH. The protective effects of estrogen on the cardiovascular system. NEJM 1999; 40: 1801-11.

15. Burke AP, Farb A, Malcolm G, Virmani R. Effect of menopause on plaque morphologic characteristics in coronary atherosclerosis. Am Heart J 2001; 141 (2 suppl.): 558-62.

16. Björck L, Wallentin L, Senestrand U, Lappas G, Rosengren A. Medication in relation to ST-segment elevation myocardial infarction in patients with a first myocardial infarction: : Swedish Register of Information and Knowledge About Swedish Heart Intensive Care Admissions (RIKSHIA). Arch Intern Med 2010; 170: 1275-81.
17. Spencer FA, Allegrone J, Goldberg RJ, Gore Jm, Fox KA Granger $\mathrm{CB}$, et al. Association of statin therapy with outcomes of acute coronary syndromes; The GRACE study. Ann Intern Med 2004; 140: 857-66.

18. Steg GP, James SK, Atar D, Badano LP, BlomströmLundquist $C$, Borger MA, et al. ESC guidelines for the management of myocardial infarction in patients presenting with ST-segment elevation. Eur Heart J 2012; 22: 2569-619.

19. Bassand JP, Hamm CW, Ardissino D, Boersma E, Budaj A, Fernández-Aviles, et al. Guidelines for the diagnosis and treatment of non-ST-segment elevation acute coronary syndromes. Eur Heart J 2007; 28: 1598-660.

20. Steg PG, Lopez-Sendon J, Lopez de Sa E, Goodman SG, Gore JM, Anderson FA Jr, et al. External validity of clinical trials in acute MI. Arch Int Med 2007; 167: 68-72.

21. Dimsdale JE. Psychological stress and cardiovascular disease. JACC 2008; 51: 1237-46.

22. Gudjonsdottir GR, Kristjansson M, Olafsson O, Arnar DO, Getz L, Sigurdsson JA, et al. Immediate surge in female visits to the cardiac emergency department following the economic collapse in Iceland: an observational study. Emerg Med J 2012; 29: 694-8.

23. Meyers DG, Neuberger JS, He J. Cardiovascular effect of bans on smoking in public places: a systematic review and meta-analysis. JACC 2009; 54: 1249-55. 


\section{Acute coronary syndromes in Landspítali 2003-2012}

\section{Gestur Porgeirsson ${ }^{1,2}$ \\ Birna Björg Másdóttir ${ }^{1}$ \\ Pórarinn Guð̃nason ${ }^{1,2}$ \\ María Heimisdóttir ${ }^{1,2}$}

Background: Marked changes in the epidemiology of acute coronary syndromes (ACS) have been observed over the last few decades in the Western Hemisphere. Incidence rates of ACS in Iceland 2003-2012 are presented.

Methods: All patients with unstable angina (UA), non ST-elevation myocardial infarction (NSTEMI) and ST-elevation myocardial infarction (STEMI) admitted to Landspitali were included in the study. Data were obtained from hospital records and changes during the period were examined.

Results: The total number of ACS cases was 7,502. STEMI incidence was reduced from $98 / 100,000$ inhabitants in 2003 to 63 in
2012 , a reduction of nearly $36 \%$. Age standardized incidence rates of STEMI declined annually by $5.5 \%$ in men and $5.3 \%$ in women ( $p$ $<0.05$ ). Incidence of NSTEMI increased from $54 / 100,000$ inhabitants in 2003 to 93 in 2012. UA patients were 56/100,000 inhabitants in 2003, 115 in 2008 and 50 in 2012. No significant annual change in age-standardized incidence rates of NSTEMI and UA was observed. About $35 \%$ of patients with NSTEMI and $30 \%$ with STEMI and UA were female. The mean age of NSTEMI patients was 72 years, five years higher than patients with STEMI and UA. About $30 \%$ of patients were living outside of the capital region.

Conclusions: $2003-2012$ there was a significant 5\% annual decrease in the number of STEMI cases and a tendency to increasing incidence of NSTEMI which by the end of the research period was the most common of the syndromes. An unusual development in the incidence of UA was observed. Possible effect of psychological stress in the society should be considered.

${ }^{1}$ Department of Internal Medicine, Division of Cardiology, Landspitali - The National University Hospital of Iceland, ${ }^{2}$ Faculty of Medicine, University of Iceland, ${ }^{3}$ Department of Finance and Information, Landspitali - The National University Hospital of Iceland.

Key words: STEMI, NSTEMI, unstable angina, incidence, troponin.

Correspondence: Gestur Porgeirsson, gesturth@landspitali.is 